\begin{tabular}{|c|c|c|}
\hline $\begin{array}{c}\text { Local Abundance and Distribution of } \\
\text { Phocoenidae and Delphinidae Families } \\
\text { in the Black Sea Territorial Waters } \\
\text { of Romania }\end{array}$ & $\begin{array}{c}\text { "Cercetări Marine“ } \\
\text { Issue no. 51 }\end{array}$ & \\
$\begin{array}{c}\text { (Romulus-Marian Paiu, Costin Timofte, } \\
\text { Angelica-Ionela Paiu, Mihaela-Elena Mirea } \\
\text { Cândea, Dumitru Murariu) }\end{array}$ & Pages 178-187 & $\mathbf{2 0 2 1}$ \\
\hline \multicolumn{2}{|c|}{ DOI:10.55268/CM.2021.51.178 } \\
\hline
\end{tabular}

\title{
LOCAL ABUNDANCE AND DISTRIBUTION OF PHOCOENIDAE AND DELPHINIDAE FAMILIES IN THE BLACK SEA TERRITORIAL WATERS OF ROMANIA
}

\author{
Romulus-Marian Paiu ${ }^{1,2}$, Costin Timofte ${ }^{1}$, Angelica-Ionela Paiu ${ }^{1}$, \\ Mihaela-Elena Mirea Cândea ${ }^{1}$, Dumitru Murariü ${ }^{2}$ \\ ${ }^{1}$ Mare Nostrum NGO, 215 Tomis Blvd., 900647, Constanta, Romania \\ ${ }^{2}$ Faculty of Biology, Bucharest University, 91-95, Splaiul Independentei, \\ R-050095, Bucharest, Romania \\ E-mail:marian_paiu@marenostrum.ro
}

\begin{abstract}
The vulnerability of the ecosystem, and mostly the Black Sea marine ecosystem, to human pressures is advisable to be assessed through indicators. Either we are speaking about human pressure or fauna and flora species, one of these indicators are filled by the marine mammal populations. Long-lived, slow-reproducing dolphins and porpoises are already recommended world-wide. During ANEMONE project we were able to perform several vessel surveys along the 12 NM area of Romanian Black Sea, between Sulina (northern border city) and Vama Veche (southern border village). The surveys were performed following distance sampling line transect methods and analyzed with Distance 7.3. software. The data were collected during spring 2019, summer 2019 and spring-summer 2020 and brings in discussion the status of the three cetacean species, abundance and distribution, in light of the latest research, and regional context, compared to the 2013 ("Adverse fisheries impacts on Cetacean population in the Black Sea" under the European Commission's "Studies for Carrying out the Common Fisheries Policy" research programme) and 2019 (CeNoBS: "Support MSFD implementation in the Black Sea through establishing a regional monitoring system of cetaceans (D1) and noise monitoring (D11) for achieving GES") survey results. The article reveals the results of these efforts and discusses the present situation of the two cetacean families present in the Romanian coastal waters.
\end{abstract}

Key-Words: dolphins, porpoises, abundance, distribution, seasons

\section{AIMS AND BACKGROUND}

The aim of the study is to report and discuss the data collected between 2010 and 2020, last decade. Emphasizing the efforts of implementing line transect distance sampling methods (Buckland et al, 2001; Zaharia et al., 2013) towards assessing the status of the two cetacean families in the 
Romanian Black Sea area.

The data regarding the cetacean group in Romanian waters are scarce, as in most of the water bodies world-wide. Although the needs of data are there, in the frame of several Agreements (eg. ACCOBAMS) and Conventions (eg. CBD; CITES) together with the European Union Habitat and Water Framework Directives (92/43/CEE; 2008/56/CEE) (Palialexis et al., 2019) and național legislation (eg. GEO 374/2004) the financial allocation were very low. To overcome this the involvement of the research group within Mare Nostrum NGO, in cooperation with national and international partners developed projects to build the capacity and implemented scientific survey for data collection. Improving in this way the data available in respect to cetacean group for Romania.

The three species, Black Sea harbour porpoise, Black Sea bottlenose dolphin and Black Sea common dolphin (Anton, 2012; Antonescu, 1966; Birkun, 2008, 2014; Cândea et al., 2012; Călinescu, 1936; Ellis, 1989; Murariu, 2005, 2012; Nicolae et al., 2017; Paiu et al., 2011, 2015, 2017, 2018, 2019, 2021; Toza et al., 2001; Zaharia, 2013) are all listed in the IUCN Red List as Endangered (harbour porpoise and bottlenose dolphin) and Vulnerable (common dolphin) and in the Annex 3 and 4 of GEO 57/2007 which ratifies the Habitats Directive in Romania. In spring of 2020 the Ministry of Environment, Waters and Forests issued the order 488/2020* which approves the List of marine endangered species in the Romanian Black Sea area (position no. 62 Delphinus delphis ponticus Barabash-Nikiforov, 1935; 63 Phocoena phocoena relicta Abel, 1905; and 64 Tursiops truncatus ponticus Barabash-Nikiforov, 1940) with the purpose of protecting and conserving the species.

\section{EXPERIMENTAL}

The data set contains primary data from dedicated surveys following line transect methods and additional from photo-identification and vantage point applied methods. Ultimately some of the data were collected within the Mare Nostrum's Monitoring and Conservation of Black Sea cetacean Program under citizen science concept. Validating and accepting the sightings with solid proofs. Standard line transects methods assume the density of animals on the surveyed transects is equal to the density in the entire study area (Buckland et al., 2001). To cover the assumption the transects were placed at random using a design where each part of the study area has an equal probability of being surveyed (uniform 'coverage probability'). Transects were designed using Distance software (Thomas et al., 2010) as equal spacing zigzags to provide a compromise between practicality and almost uniform coverage probability. The transects were designed to start and terminate slightly outside the survey blocks ('plus sampling') to prevent 'edge effects' from compromising 
uniformity of coverage.

Distance software was used also for data analysis, estimating abundances of the three species (Paiu et al., 2019).

A single platform method was implemented, determined by the overall conditions and restraints. The area focused on was Romanian territorial waters (TW) boundaries. The design follows the equal spaced zigzag design class, within the 12 nautical miles area (territorial waters TW) of Romania, between Vama Veche (Southern border) and Sulina (Northern border) (Fig. 1.). Beside the ANEMONE surveys which were performed in all the above-mentioned area, there were two other surveys performed only in the southern part, between Constanta (North) and Vama Veche (South) following perpendicular on the shore transect design. The overall proportion of the stratum sampled was between 7\% (2019-2020) and 39.6\% (2017). This also influenced the area of the study, entire TW surface being estimated to $5871,423 \mathrm{Km}^{2}$ as for the southern part only $1063 \mathrm{Km}^{2}$. There were used two types of platforms for the expeditions, sailing yacht with motor, equipped with single platform and a motorboat. Both options with similar hights. The team on effort was comprised by two observers which surveyed the area between abeam and $90^{\circ}$ angle to the right and left of the boat and a data recorder that was responsible to note all the data from the two observers. Each position was changed in a 30minute sequence. Survey speed was between 5-9 kts $(9.26-16.66 \mathrm{~km} / \mathrm{h})$. Angles were collected with the help of angle boards and Fujinon binoculars with compass following Birkun et al., 2014 and Heinemann, 1981 methods. To collect the distances Zeiss binocular with electronic range finder, Fujinon CMP binocular and distance ruler were used. To obtain the precise measurement of the perpendicular distance to the animal or group of animals Lerczak \& Hobbs (1998) methods was used. Environmental conditions: sea state, glare, cloud cover, turbidity and a subjective assessment of overall conditions were recorded at the beginning of each transect and whenever a change occurred. Due to the limited time available for the survey and unfavourable hydrometeorological forecast, the observers remained active even in poor conditions with sea state of 4 on the Beaufort scale. Observers searched a $110^{\circ}$ arc from abeam to ahead with naked eyes and binoculars for species identification. When a sighting was made, the following data were recorded: angle of the sighting to the transect line, radial distance, species, group size (min-max-best estimate), initial cue, estimated swim direction, behaviour, and name of the observer who made the sighting. Tracks and coordinates were recorded, using the GPS navigator Garmin Etrex 30. For quality assessment, digital pictures of the whole group and individuals were taken; animals were counted, and school size were recorded. Action was performed only "on effort" mode. Analysis was performed Distance 7.3. software package (Thomas et al. 2010). 
Previous survey using the same protocol in the area were the "Adverse Fisheries Impacts on Cetacean Populations in the Black Sea" study (Birkun et al., 2014). Following it the line transect distance sampling surveys were designed and performed.

Angle to sightings was measured with fixed angle-boards that, together with the measured distance with the help of 7x50 WPC-CF Fujinon Mariner Binoculars, provided a precise measurement of the perpendicular distance to the animal or group of animals.

The overall effort for the dedicated surveys following distance sampling was of round $1000 \mathrm{NM}$, and 24 days. The total effort on the reported data is of 173 days in which cetacean were observed, not including the days without observations. When it comes to sightings from shore vantage point method (Nuuttila \& Mendzil, 2014; Evans and Hammond, 2004; Diederichs et al., 2008; Boyd et al., 2010; Bas et al., 2014; Todd et al., 2015; Benedek, 2013; Geraci \& Lounsbury, 1998) was applied and for photo-identification method the ACCOBAMS guidelines (2004; 200X) and of Wilson et al., 1999; Culloch \& Robinson, 2008; Gol'din et al., 2017, Paiu et al., 2011, 2014; Benedek, 2013.

All the data were submitted to OBIS SEAMAP repository (Paiu et al., 2019b).

\section{RESULTS AND DISCUSSION}

This report is meant to provide background information on the abundance and distribution of the three cetacean species present in the Romanian territorial waters collected within Mare Nostrum's program and support the effort towards management and conservation of the species.

The area includes nine Natura 2000 marine protected areas: ROSPA0076 Black Sea, ROSCI0066 Danube Delta-Marine zone, ROSCI0413 Lobe of Zernov Phyllophora Field, ROSCI0197 Eforie North Eforie South Submerged beach, ROSCI0273 Marine Area of Cape Tuzla, ROSCI0293 Costinesti - 23 August, ROSCI0281 Cape Aurora, ROSCI0094 Mangalia Sulphide Seeps, ROSCI0269 Vama Veche-2 Mai (https://natura2000.eea.europa.eu/Natura2000), whereas 2 species of cetaceans (Tursiops truncatus ponticus and Phocoena phocoena relicta) are referred to in Article 4 of Directive 2009/147/EC and listed in Annex II of Directive 92/43/EEC for all SCI areas (Fig. 1). (Natura 2000 Network view and Standard Data forms**).

The entire database analyzed includes 720 sightings of 1782 individuals from the three species (Table 1). From these 144 sightings are registered in the north part and the rest, 576, in the southern part of the area.

The Figure 1 reiterates the species are using the area, offering an overall picture in time and space overlapping the 10 years data collection effort. At 
the same time the presented distribution is tributary to the effort imposed in data collection, being directly affected by the number of surveys. With most sightings recorded in spring and summer seasons (Fig. 2).

Table 1. Distribution in time of the recorded sightings between 2010-2020, in Romanian 12 NM area

\begin{tabular}{|c|c|c|c|c|c|}
\hline Year & Cetacea & $\begin{array}{c}\text { Delphinus } \\
\text { delphis } \\
\text { ponticus }\end{array}$ & $\begin{array}{c}\text { Phocoena } \\
\text { phocoena } \\
\text { relicta }\end{array}$ & $\begin{array}{c}\text { Tursiops } \\
\text { truncatus } \\
\text { ponticus }\end{array}$ & $\begin{array}{c}\text { Grand } \\
\text { Total }\end{array}$ \\
\hline 2010 & - & 3 & 1 & 2 & 6 \\
\hline 2011 & - & 3 & 10 & 5 & 18 \\
\hline 2012 & - & - & 14 & 7 & 21 \\
\hline 2013 & - & 8 & 11 & 21 & 40 \\
\hline 2014 & - & 5 & 3 & 11 & 19 \\
\hline 2015 & - & 1 & 3 & 12 & 16 \\
\hline 2016 & - & 2 & 3 & 21 & 26 \\
\hline 2017 & 2 & 10 & 234 & 58 & 304 \\
\hline 2018 & - & 1 & 13 & 18 & 32 \\
\hline 2019 & - & 20 & 20 & 68 & 108 \\
\hline 2020 & - & 18 & 69 & 43 & 130 \\
\hline Grand & $\mathbf{2}$ & $\mathbf{7 1}$ & $\mathbf{3 8 1}$ & $\mathbf{2 6 6}$ & $\mathbf{7 2 0}$ \\
Total & & & & & \\
\hline
\end{tabular}

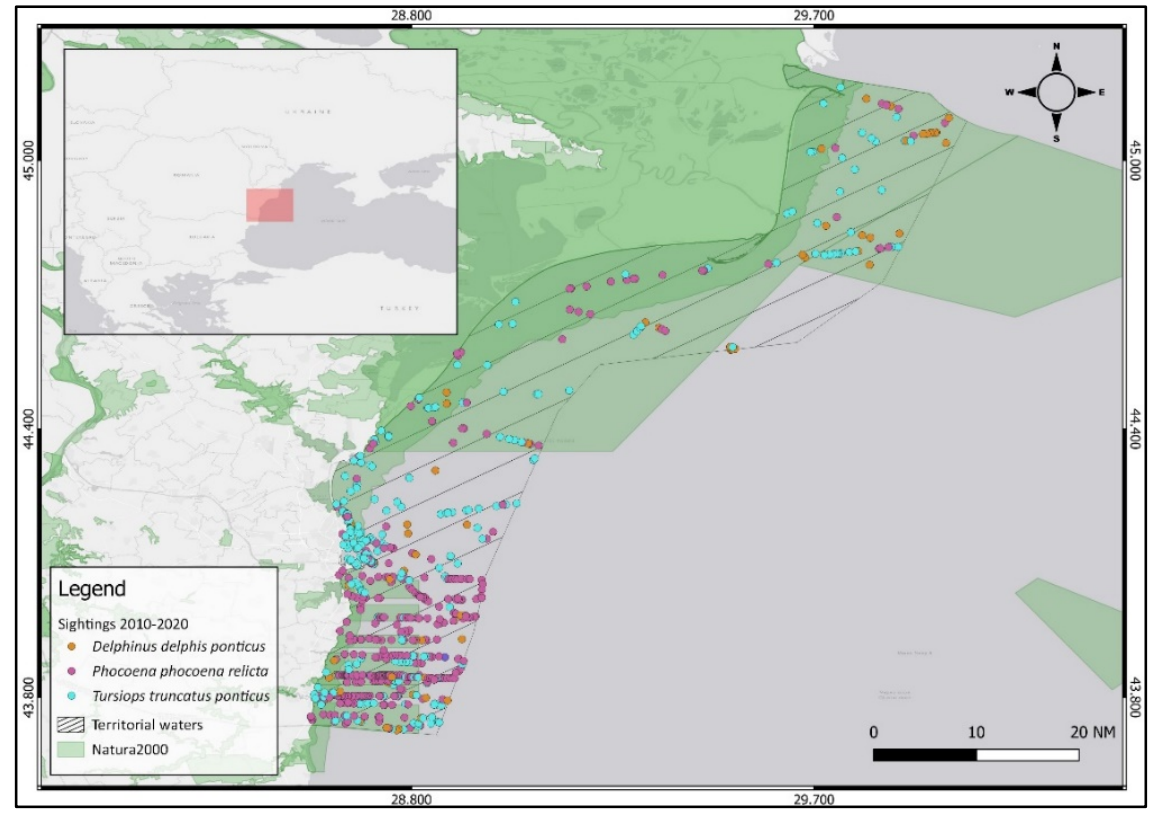

Fig. 1. Sighting of the three cetacean species, between 2010 and 2020, within the 12 NM Romanian area. Highlighting the marine protected areas found in the perimeter 
Higher density of sightings in southern part can be explained also through the greater effort applied in the area despite the rough conditions and accessibility, whereas in the north part is required more effort for surveys. Several limiting factors for surveying in the northern part of the Romanian coastline are the difficult accessibility in the Danube Delta Protected area and the lack of harbors mainly because the infrastructure is poorly developed. These two factors make almost impossible to apply the citizen science concept due to the fact that there are strictly protected areas where the access is prohibited for citizen. Moreover, the lack of harbors, funds and the instability of the Black Sea are making the surveys to imply more effort and difficulty towards completing them.

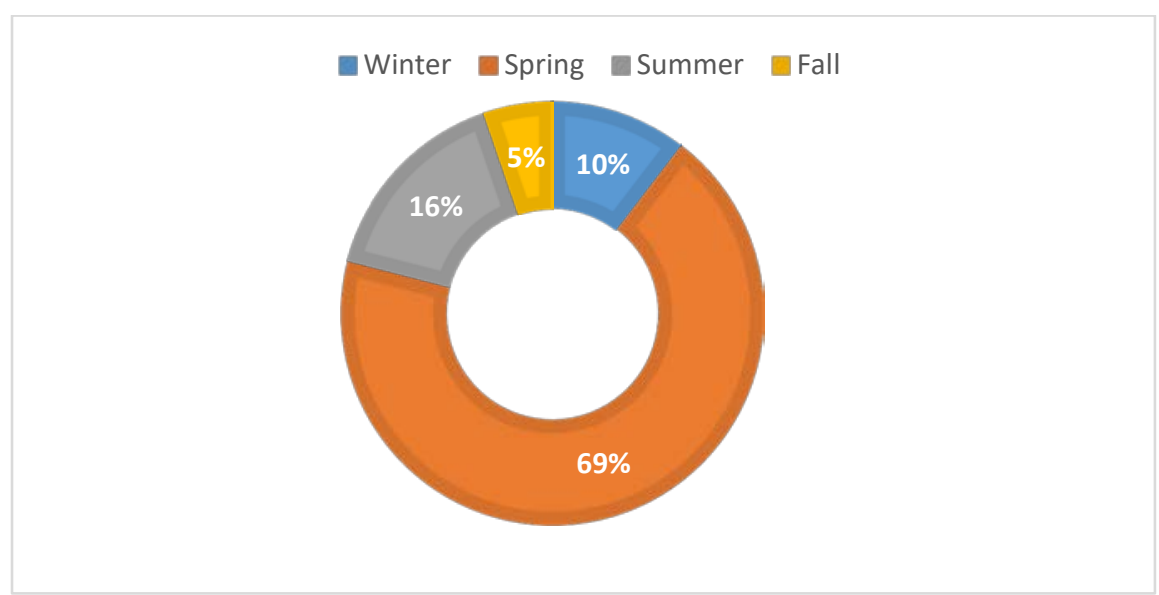

Fig. 2. Seasonal distribution of sightings, between 2010 and 2020, within the 12 NM Romanian area. Highlighting the warm season availability of data

If the distribution data are more achievable to be collected and disseminated (Nicolae et al., 2017; Radu et al., 2013), abundance data are hard to obtain, either because of lack of funds or simply because of lack of expertise. During the studied period we collected and assessed data to determine abundances of the three species in 5 expeditions, 3 in the frame of ANEMONE) project (ANEMONE Deliverable 4.3., 2021) covering all the area and 2 in the frame of an ACCOBAMS financed project (Paiu et al., 2017), just for the southern part of the study area. Beside these, two large scale surveys were performed and also covered the interest area, one in 2013 by Birkun and colleagues and one in 2019 under CeNoBS project by Paiu and colleagues (2021b). These are the only abundance data available so far and which are compiled below for the waters of Romania (Table 2). 
Table 2. The abundance estimates of the three cetacean species by means of distance sampling analysis performed within the report period

\begin{tabular}{|c|c|c|c|c|c|}
\hline \multirow[t]{2}{*}{ Species } & \multirow[t]{2}{*}{ Project/Season } & \multicolumn{2}{|c|}{$\begin{array}{c}\text { Density of animals, } \\
\text { indv./km2 }\end{array}$} & \multicolumn{2}{|c|}{ Number of animals } \\
\hline & & D & $95 \% \mathrm{CI}$ & $\mathbf{N}$ & $95 \% \mathrm{CI}$ \\
\hline \multirow{7}{*}{$\begin{array}{l}\text { Harbour } \\
\text { porpoises }\end{array}$} & MEP/summer & 1.205 & $0.589-2.468$ & 7023 & $3431-14378$ \\
\hline & $\begin{array}{l}\text { ACCOBAMS/ } \\
\text { spring }\end{array}$ & 0.337 & 0.119-0.955 & 359 & $127-1015$ \\
\hline & $\begin{array}{c}\text { ACCOBAMS/ } \\
\text { summer }\end{array}$ & 5.359 & $2.821-10.183$ & 5697 & 2999-10824 \\
\hline & $\begin{array}{l}\text { ANEMONE/ } \\
\text { spring }\end{array}$ & 0.09 & $0.036-0.234$ & 536 & $209-1375$ \\
\hline & $\begin{array}{l}\text { ANEMONE/ } \\
\text { summer }\end{array}$ & 0.103 & $0.016-0.642$ & 333 & $53-2074$ \\
\hline & $\begin{array}{l}\text { ANEMONE/ } \\
\text { summer }\end{array}$ & 0.643 & $0.329-1.255$ & 3775 & $1934-9475$ \\
\hline & $\begin{array}{l}\text { CeNoBS/ } \\
\text { summer }\end{array}$ & 0.426 & $0.217-0.834$ & 10887 & $8414-14489$ \\
\hline \multirow{6}{*}{$\begin{array}{l}\text { Common } \\
\text { dolphin }\end{array}$} & MEP/summer & 0.279 & $0.113-0.685$ & 1624 & $660-1993$ \\
\hline & $\begin{array}{c}\text { ACCOBAMS/ } \\
\text { summer }\end{array}$ & 0.153 & $0.0491-0.480$ & 163 & $52-510$ \\
\hline & $\begin{array}{l}\text { ANEMONE/ } \\
\text { summer }\end{array}$ & 0.176 & $0.050-0.672$ & 1032 & $336-3626$ \\
\hline & $\begin{array}{l}\text { ANEMONE/ } \\
\text { summer }\end{array}$ & 0.149 & $0.064-0.343$ & 873 & $378-2015$ \\
\hline & $\begin{array}{l}\text { CeNoBS/ } \\
\text { summer }\end{array}$ & 0.143 & & 3661 & $2772-4966$ \\
\hline & MEP/summer & 0.217 & $0.131-0.359$ & 1265 & $766-2089$ \\
\hline \multirow[t]{6}{*}{$\begin{array}{l}\text { Bottlenose } \\
\text { dolphin }\end{array}$} & $\begin{array}{l}\text { ACCOBAMS/ } \\
\text { spring }\end{array}$ & 0.627 & $0.201-1.957$ & 667 & $214-2080$ \\
\hline & $\begin{array}{c}\text { ACCOBAMS/ } \\
\text { summer }\end{array}$ & 0.424 & 0.194-0.927 & 451 & $207-986$ \\
\hline & $\begin{array}{l}\text { ANEMONE/ } \\
\text { spring }\end{array}$ & 0.293 & $0.116-0.738$ & 1719 & $682-4335$ \\
\hline & $\begin{array}{l}\text { ANEMONE/ } \\
\text { summer }\end{array}$ & 0.837 & $0.339-2.063$ & 2705 & $1097-6670$ \\
\hline & $\begin{array}{c}\text { ANEMONE/ } \\
\text { summer }\end{array}$ & 0.337 & $0.161-0.708$ & 1980 & $944-4156$ \\
\hline & $\begin{array}{l}\text { CeNoBS/ } \\
\text { summer }\end{array}$ & 0.243 & $0.129-0.372$ & 6208 & $3968-10325$ \\
\hline
\end{tabular}

*The CeNoBS figures are for the TW+EEZ of Romania.

\section{CONCLUSIONS}

The research presented by the authors is providing a report of the available data on cetaceans within the 12 NM area for the period 2010-2020. It also compares the results of several standard surveys following line transect distance sampling. 
Distribution and the presence of species in different quarters of the year, less winter, not covered by the surveys, it supports to certain extent the general conclusion that most probably dolphins and porpoises are migrating in these waters for feeding and breeding. The question that arises is whether cetaceans are leaving the territorial waters in late autumn following the migration of fish towards southeastern Black Sea, because there are recordings in winter season as well. Even though the recordings are low in number this can indicate the possibility of resident or semi-resident populations using the territorial waters or the western part of the basin all year round.

This question underlines the need of a dedicated and standardized monitoring program with the objective of determining the trends in the cetacean population using the Romanian territorial waters and resident populations.

Acknowledgement. This work has been carried-out with financial support from the projects ANEMONE "Assessing the vulnerability of the Black Sea marine ecosystem to human pressures" with the financial support from the Joint Operational Programme Black Sea Basin 2014-2020.

\section{REFERENCES}

Anton E., Nicolaev S., Radu G., Maximov V. (2012), Research on the selectivity of the pelagic trawls used in the Romanian costal fishery with trawls tonnage vessels. J Environ Prot Ecol, 13 (3A): 1783-1791.

ACCOBAMS guidelines (2004), Guidelines for the development of national networks of cetacean stranding monitoring network. Tunis. 1-19. GL_Developmenthttps://www.accobams.org/wpcontent/uploads/2018/0 9/GL_Development_National_Networks_Strandings.pdf_National_Net works_Strandings.pdf (accobams.org) accessed at 13.08.2021.

ACCOBAMS guidelines 200X, Guidelines for the establishment of tissue banks and ethical code. Tunis. 1-19. https://www.accobams.org/wpcontent/uploads/2018/09/GL_granting_exceptions_article-II1.pdf accessed at 13.08.2021.

Bas A., Öztürk A., Öztürk B. (2014), Selection of critical habitats for bottlenose dolphins (Tursiops truncatus) based on behavioral data, in relation to marine traffic in Istanbul Strait, Turkey, Marine Mammal Science. 10.11111/mms.1202. 1-19.

Benedek A-M. (2013), Expertise of fauna and animal communities laboratory notes. Sibiu, Romania, 44-55. http://www.ecologia-lasibiu.ro/wp-content/uploads/2017/06/Material-curs-Expertiza-simonitoringul-faunei.pdf accessed at 12.08.2021 (in Romanian). 
Birkun Jr. A., Northridge S.P., Willsteed E.A., James F.A., Kilgour C., Lander M., Fitzgerald G.D. (2014), Studies for Carrying Out the Common Fisheries Policy: Adverse Fisheries Impacts on Cetacean Populations in the Black Sea. Final report to the European Commission, Brussels, Belgium, $348 \mathrm{p}$.

Boyd I.L, Bowen W.D and Iverson S.J. (Eds.) (2010), Marine Mammal Ecology and Conservation: A Handbook of Techniques. Oxford University Press, $121 \mathrm{p}$.

Culloch R.M. and Robinson K.P. (2008), Bottlenose dolphins using coastal regions adjacent to a Special Area of Conservation in north-east Scotland. Journal of the Marine Biological Association of the United Kingdom, 88(6):1237-1243.

Diederichs A., Gruenkorn T. and Nehlds G. (2003), Do porpoise detectors detect porpoises? Proceedings of the European Cetacean Society Annual Meeting Las Palmas, The Canary Islands.

Evans P.G.H., Hammond P.S. (2004), Monitoring cetaceans in European waters. Mammal Review, 34: 131-156.

Gol'din P., Gladilina E., Savenko O., Vishnyakova K., Neprokin O., Ivchenko, Ye. (2017), Identification and initial assessment of cetacean groupings in coastal waters of the north-western Black Sea, Ukrainian sector (progress report). MoU ACCOBAMS Nº9/2016/FAC, 1-97.

Heinemann D. (1981), A rangefinder for pelagic bird censusing. Journal of Wildlife Management, 45: 489-493.

Geraci J.R. and Lounsbury V.J. (1998), Marine Mammals Ashore. A Field Guide for Strandings. NOAA and National Aquarium in Baltimore, CDROM version. Guide of strandings - MEDACES (uv.es) accessed at 13.08.2021.

Lerczak J., Hobbs R. (1998), Calculating sighting distances from angular readings during shipboard, aerial, and shore-based marine mammal surveys. Marine Mammal Science, 14: 559 - 599.

Murariu D. (2005), Mammalia (Mammals). In: Botnariuc \& Tatole (Eds.) The Red Book of Vertebrates in Romania, Edit. Academiei Române. București, 59-61 (in Romanian).

Murariu D. (2012), From the world of mammals. Edit. Academiei Române. București, 6: 58-149 (in Romanian).

Nicolae C., Nenciu M, Filimon A., Spanu A., Marin M., Pogurschi E. (2017), Study on Conservation Status of Marine Mammals in the Danube Delta Marine Zone (RoSCI 0066). J Environ Prot Ecol, 18(3): 1005-1016.

Nuuttila H.K. and Mendzil A. (2014, unpublished), Development of marine mammal observation methods for vantage Point surveys in Ramsey sound. SEACAMS Project Report 2014-D75. 
Paiu R.M. et al (2021), ANEMONE Deliverable 4.3. Citizen science - a tool to assess cetacean population status, $43 \mathrm{pp}$, CD Press.

Paiu R.M. (2017), Increase the regional capacity for developing cetacean distribution and abundance studies. Final Report. ACCOBAMS Secretariat, 1-74.

Paiu R.M., Mirea Candea M.E., Paiu A.I., Gheorghe A.M. (2018), New data on the abundance and distribution of the Black Sea dolphins and porpoises (Cetaceea: Delphinidae; Phocoenidae) from the Romanian territorial waters. International Zoological Congress of "Grigore Antipa” Museum. 21-24 November 2018. Bucharest. Poster 144.

Paiu R.M., Olariu B., Paiu A.I., Mirea Candea M. E., Gheorghe A. M., Murariu D. (2019), Cetaceans in the coastal waters of southern Romania: initial assessment of abundance, distribution, and seasonal trends. Journal of Black Sea / Mediterranean Environment, 25(3): 266-279.

Paiu R. M., Fujioka E., Paiu A., Mirea Candea M. E., Gheorghe A. M., Timofte C. (2019b), Integration of cetacean monitoring data into databases such as OBIS-SEAMAP, to advance spatially-explicit ecological assessments. Marina RRI-SIS Conference, 12-21.

Paiu R.M., Panigada S., Canadas A., Gol'din P., Popov D., David L., Amaha Ozturk A., Glazov D (2021b), Estimates of abundance and distribution of cetaceans in the Black Sea from 2019 surveys. Ed. ACCOBAMS ACCOBAMS Survey Initiative/CeNoBS Projects, Monaco, 54 p.

Paiu R.M, (2011), Working protocol on the photo-identification method of cetaceans. Constanța, Romania, ONG Mare Nostrum, 23 p (in Romanian).

Paiu R.M, Cândea M., Iosif A., Gheorghe A., Drăghici A. (2014), Photoidentification of cetaceans - photo album. Constanța, Romania, ONG Mare Nostrum, 23 p. (in Romanian).

Paiu R.M, Cândea M. (2015), Correlation of cetacean stranding events between 2010-2014 at the Romanian coast. Cercetări Marine/Marine Research, 46: 144-155.

Radu G., Anton E., Nenciu M, Spînu A. (2013), Distribution and abundance of cetaceans in the Romanian marine area. Cercetări Marine/Marine Research, 43: 320-341.

Todd V., Todd I., Gardiner J., Morrin E. (2015), Marine Mammal \& Passive Acoustic Monitoring Handbook. ISBN 978-1-907807-66-4.1-859.

Wilson B., Hammond P.S., Thompson P.M. (1999), Estimating size and assessing trends in a coastal bottlenose dolphin population. Ecological Applications, 9: 288-300.

Zaharia T., Anton E., Radu G. (2013), Synthetic monitoring guide for marine species and coastal and marine habitats of community interest in Romania. Ed Boldaș. ISBN 978-606-8066-45-5. 22-42 (in Romanian).

** Order 488/2020 | Free legislation (legex.ro) 